\title{
Insights into an Early Jurassic dinosaur habitat: ichnofacies and enigmatic structures from the Portland Formation, Hoover Quarry, Massachusetts, U.S.A.
}

\author{
Joseph H. Collette ${ }^{1}$, Patrick R. Getty ${ }^{2 *}$, and James W. Hagadorn ${ }^{3}$ \\ 1. Department of Earth Sciences, 900 University Ave., University of California, Riverside, California 92521, U.S.A. \\ 2. Center for Integrative Geosciences, University of Connecticut, 354 Mansfield Road, Storrs, Connecticut 06269, USA \\ 3. Department of Earth Sciences, Denver Museum of Nature \& Science, 2001 Colorado Boulevard, Denver, Colorado 80205, U.S.A. \\ *Corresponding author < patrick.getty@uconn.edu>
}

Date received: 9 September 2010 Date accepted 17 February 2011

\begin{abstract}
Jurassic sandstones of the Hartford Basin are well known for their dinosaur trackways, but few studies have characterized their invertebrate ichnofaunas. A notable Portland Formation exposure in this area is the Hoover Quarry in East Longmeadow, Massachusetts, where vertebrate skeletal material (the type specimen of the crocodilian Stegomosuchus longipes) occurs in association with a diverse ichnofauna. Hoover Quarry ichnogenera include Eubrontes cf. gracilis, Planolites beverleyensis, Planolites montanus, probable Scoyenia burrows, and Skolithos isp. Also preserved at the site is Palaeophycus tortuosus, a sinusoidal burrow that had been previously synonymized with Palaeophycus tubularis. A probable Skolithos burrow termination with an unusual pattern of scratches also occurs, along with several problematic stellate structures. At this site, primary sedimentary structures on trace bearing surfaces are consistent with deposition in a shallow aquatic environment that was periodically emergent. Viewed in the context of nearby sections of the Portland Formation, Hoover Quarry exposures could have been deposited in fluvial, ephemeral lacustrine, or playa environments. Traces in the Hoover Quarry indicate Scoyenia-Skolithos-composite ichnofacies, elements of which are commonly produced in continental firmground environments.
\end{abstract}

\section{RÉSUMÉ}

Les grès du Jurassique dans le bassin de Hartford sont reconnus pour la présence d'empreintes de dinosaures. Mais peu d'études ont permis de caractériser l'ichnofaune invertébrée qu'on peut également y observer. Un affleurement notable de la Formation Portland dans la région est présent dans la carrière Hoover, à East Longmeadow, au Massachusetts, où des matériaux de squelettes de vertébrés (le spécimen type du crocodilien Stegomosuchus longipes) et une ichnofaune diversifiée sont présents. L'ichnofaune de la carrière Hoover comprend les espèces comme Eubrontes cf. gracilis, Planolites beverleyensis, Planolites montanus, vraisemblablement des terriers de Scoyenia, et Skolithos. Il y a également sur le site l'espèce Palaeophycus tortuosus, un terrier sinusoïdal qui a déjà été nommé Palaeophycus tubularis. L'extrémité d'un terrier de l'espèce probable Skolithos accompagnée d'une série inusitée de stries ou d'éraflures est en outre présente, tout comme plusieurs structures étoilées dont l'origine demeure mystérieuse. Sur le site, des structures primaires sur des surfaces marquées de traces correspondraient à une sédimentation dans un milieu aquatique peu profond qui a émergé à intervalles périodiques. Considéré dans le contexte des sections de la Formation Portland, situées à proximité, le dépôt des affleurements de la carrière Hoover pourrait être survenu dans un milieu fluvial, lacustre éphémère ou en présence d'un lac temporaire. Les traces relevées dans la carrière Hoover indiquent la présence d'un ichnofaciès composite de type Scoyenia-Skolithos, dont les éléments sont couramment produits dans un milieu de sol continental à cohésion moyenne.

[Traduit par la redaction]

\section{INTRODUCTION}

The Hartford Basin of western Massachusetts and Connecticut has been a productive vertebrate trace fossil region since the early Nineteenth Century. Dinosaur footprints were found as early as 1802 in South Hadley, Massachusetts (Hitchcock
1865). Even though work has continued on the vertebrate ichnologic record of the Hartford and related Deerfield Basins (e.g., Olsen et al. 1998; Olsen and Rainforth 2003; Rainforth 2003; Getty 2005), few modern studies have examined the abundant invertebrate trace fossils of the region. Among these few, Gierlowski-Kordesch $(1985,1991)$ identified a Scoyenia 
ichnofacies in the Lower Jurassic (Hettangian) East Berlin Formation, concluding that tracemakers employed opportunistic life strategies based around the availability of water in playa and ephemeral alluvial plain settings.

In this contribution we examine a suite of non-marine strata comparable to that of Gierlowski-Kordesch's studies and exposed in the Hoover Sandstone Quarry in East Longmeadow, Massachusetts, in order to characterize the paleoecology of the fauna and to augment our understanding of Scoyenia and related continental ichnofacies (sensu Smith et al. 1993; Keighley and Pickerill 2003; Lawfield and Pickerill 2006). In addition to describing the invertebrate traces, we examine vertebrate tracks and previously recovered vertebrate skeletal material from the Hoover Quarry, and integrate this paleontological data with limited sedimentologic and regional stratigraphic information to help place the Hoover Quarry trace association within known ichnofacies.

\section{GEOLOGICAL SETTING}

The Hoover Quarry is located in the town of East Longmeadow, Massachusetts $\left(42^{\circ} 3^{\prime} 30.03^{\prime \prime} \mathrm{N}, 72^{\circ} 29^{\prime} 19.51^{\prime \prime} \mathrm{W}\right.$; Fig. 1A). Quarrying operations took place from the late Nineteenth Century into the 1920s, producing "Portland Brownstone" that was used locally for construction. The quarry is now flooded and collecting is restricted to talus piles around the pit. The undivided upper Portland Formation of Olsen et al. (2005) is exposed at the quarry, and the lithology varies from plane bedded, clay-draped sandstone to flaser cross-bedded sandstone. Primary structures include abundant mudcracks, rare asymmetrical ripples, raindrop impressions, and mud chips. Trace fossils are abundant and are preserved in both concave epirelief and convex hyporelief on bed surfaces and soles.

The Portland Formation is the youngest unit of the Newark Supergroup within the Hartford Basin (Fig. 1A), which is one

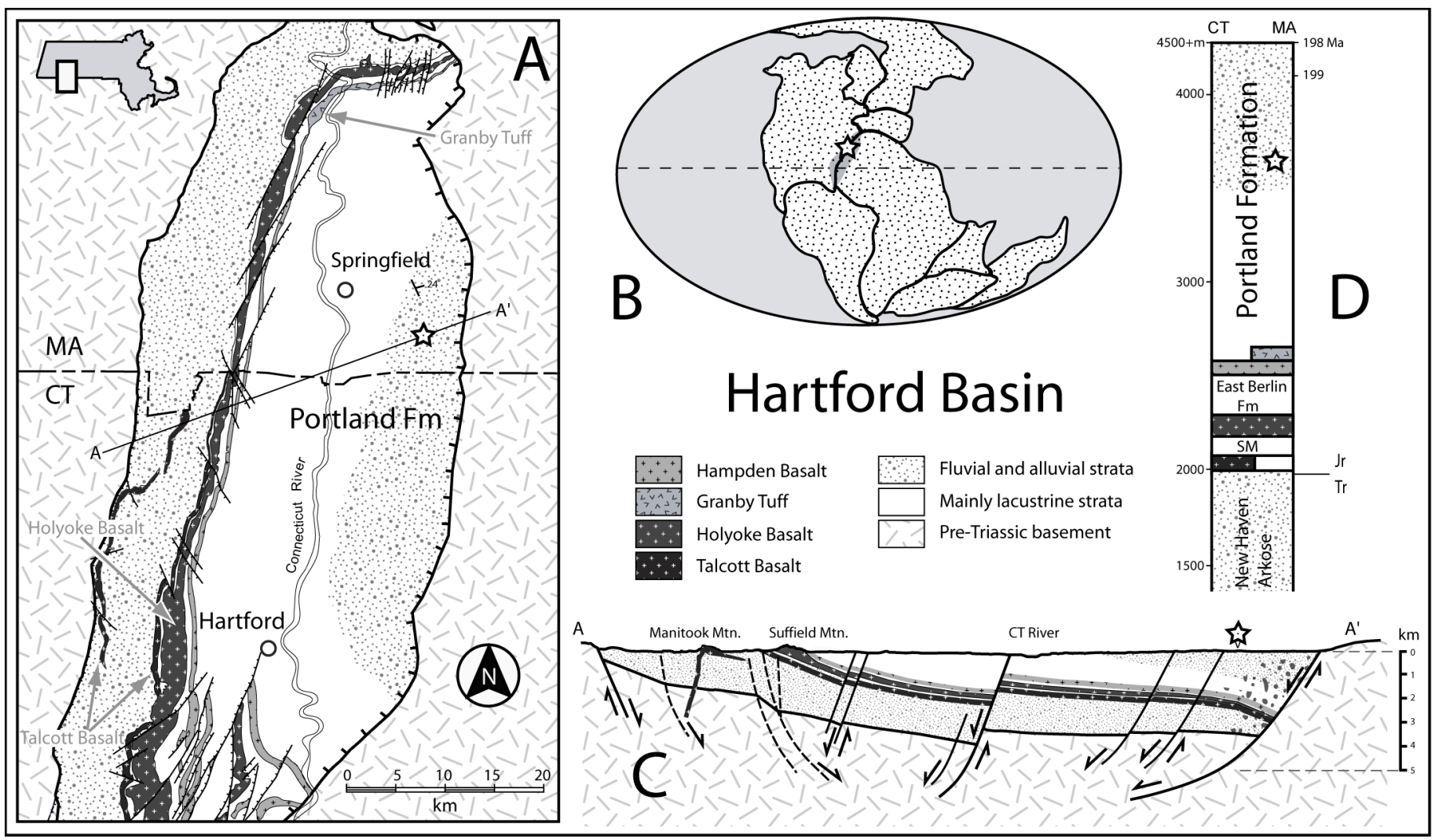

Fig. 1. (A) Hartford Basin map showing the distribution of lithologic units and depositional facies. Formations on the map (from west to east) are the New Haven Arkose, Talcott Basalt, Shuttle Meadow Fm (thin white band), Holyoke Basalt, East Berlin Fm (slightly thicker white band), Hampden Basalt, and Portland Formation. The star represents the location of the Hoover Quarry, East Longmeadow, Massachusetts, where the specimens described herein were collected. Map modified from Olsen et al. (1989) and Hubert et al. (1992). (B) Pangaea at the Carnian/Norian boundary (Late Triassic, 225 Ma). The shaded area shows the general distribution of Newark Supergroup strata. Modified from Olsen et al. (1992). (C) Cross-section through the Hartford Basin (A to A' in Fig.1A) showing major units and their relationships. Star represents the approximate location of the Hoover Quarry. Cross-section modified from Wise (1992). (D) Generalized stratigraphic section of the Hartford Basin, modified from Olsen et al. (1998), showing the age of the strata. Star shows approximate location of the Hoover Quarry in the column. SM = Shuttle Meadow Fm. 
of a series of filled rift basins that formed during the breakup of Pangaea (Fig. 1B). Rifting is generally thought to have occurred through the Late Triassic and Early Jurassic (Olsen et al. 2005), with the Portland Formation considered HettangianPleinsbachian in age. Although some recent work (e.g., Cirilli et al. 2009) suggests that almost all of the Newark Supergroup is of Late Triassic age, we follow the ages established by Olsen et al. (2005) A fault-bounded asymmetrical half-graben, the Hartford Basin is over $140 \mathrm{~km}$ long, extending from Long Island Sound in Connecticut to near Amherst, Massachusetts (Olsen et al. 1989; Hubert et al. 1992; Fig. 1C, D). Gradual subsidence of the basin along an eastern listric normal fault allowed accumulation of over $4 \mathrm{~km}$ of sediment and basalt during extension (Hubert et al. 1992; McDonald 1992).

The upper Portland Formation (Pleinsbachian) consists of 1000 to $2000 \mathrm{~m}$ of fluvial and alluvial-fan red-bed sandstones, mudstones, and conglomerates (Hubert et al. 1992; McDonald 1992; Olsen et al. 2005; Wolela and Gierlowski-Kordesch 2007). Sediments were derived from fault-bounded pre-Triassic crystalline highlands to the east, from which alluvial fans spread westward across the basin. Sediment may have also come from eastward flowing rivers, but later erosion has removed any such strata (Hubert et al. 1992). As extension waned in the Pleinsbachian, the rate of subsidence decreased and sediments filled the basin to the outlet, resulting in an open basin in which the mainly fluvial upper Portland Formation was deposited (Olsen et al. 1989, 2005; Olsen 1997; Hubert et al. 1992).

Sedimentary structures observed in talus at the Hoover Quarry are consistent with deposition in a monsoonal climate in a fluvial or ephemeral lacustrine setting. Furthermore, the presence of asymmetric ripples, desiccation cracks, mud chips, and raindrop impressions indicate that many of the specimens studied were deposited in a shallow aquatic setting characterized by intermittent subaerial exposure.

\section{SYSTEMATIC ICHNOLOGY}

\section{Ichnogenus Pterichnus Hitchcock, 1865}

\section{cf. Pterichnus isp.}

(Fig. 2A)

DESCRIPTION: Gently curving trackway composed of a series of arcuate scratches transverse to the trackway axis, preserved as convex hyporelief on bed sole. Scratches regularly spaced, gently curved to straight, many passing through the central axis of the trackway, forming an angle of $45-55^{\circ}$ with the midline of the trackway. Central portion of trackway poorly defined due to overlap of individual striae. Trackway $8-10 \mathrm{~mm}$ wide by $7.5 \mathrm{~cm}$ long; individual striae $1-3 \mathrm{~mm}$ in length by $0.4-0.6 \mathrm{~mm}$ wide.

REMARKs: The parallel scratch marks of this trace are similar to oblique scratches in the ichnogenera Glaciichnium and Pterichnus, which were produced by isopods (Gaillard et al. 2005; Uchman et al. 2009). However, Glaciichnium is composed of multiple imprints per set, with the medial imprints nearly parallel to the trackway axis (Uchman et al. 2009). In contrast, the present trace shows only a single scratch set oriented at an angle to the trackway midline, and these scratches may cross the trackway midline oblique to the trackway axis. The morphology of this trace is somewhat more similar to variants of Pterichnus produced in humid, but not saturated, sediments (Gaillard et al.2005), although the track sets do not typically cross the trackway midline in Pterichnus.

There are two ichnospecies of Pterichnus: Pterichnus tardigradus and Pterichnus isopodichus. One of the main differences between the two is in the symmetry of the trackways (Gaillard et al. 2005). Pterichnus tardigradus has oppositely symmetric scratch/imprint sets, whereas Pterichnus isopodicus has alternately symmetric sets. Unfortunately the Hoover Quarry trace is only well preserved on one side of the trackway, and therefore the original symmetry is difficult to ascertain. We tentatively assign this trace to Pterichnus pending the discovery of more complete material.

\section{Ichnogenus Eubrontes Hitchcock, 1845}

\section{Eubrontes cf. gracilis}

(Fig. 2B)

DESCRIPTION: Small bipedal, tridactyl, right theropod pes impression preserved in convex hyporelief, $7 \mathrm{~cm}$ long and 4.6 $\mathrm{cm}$ wide. No hallux or claw impressions present. Digit III projection ratio is 2.3 , ratio of digit III/II is 1.53 , ratio of digit III/ IV is 1.11. The number of pads is 2 on digit II, 3 on digit III, and 4 on digit IV. Digit pads are separated by a single crease. Metatarsal-phalangeal pads are visible behind digits III and IV. Divarication of outer digits is $36^{\circ}$.

REMARKs: The four common functionally tridactyl dinosaurian ichnogenera are Anchisauripus, Anomoepus, Eubrontes, and Grallator. Anomoepus was made by an ornithischian, whereas theropods made Anchisauripus, Eubrontes, and Grallator (Olsen et al. 1998; Olsen and Rainforth 2003). The pad morphology of this footprint is unlike that of Anomoepus, in which the metatarsal-phalangeal pad of digit IV lies very close to or directly behind digit III, and in which all pads are separated by two creases (Olsen and Rainforth 2003). Rather, the pad morphology of this footprint is similar to theropod tracks, in which the metatarsal-phalangeal pad of digit IV lies laterally to a line drawn down the centre of digit III and a single crease separates the pads.

The size of this footprint is similar to that of Grallator, the smallest of the theropod ichnotaxa; however, the footprint shows characteristics, such as a low digit III projection ratio and high angle of divarication, which occur in Anchisauripus and Eubrontes. Thus, the footprint does not fit well into any of the three ichnogenera as defined by Olsen et al. (1998). Indeed, Olsen et al. expressed concern about whether these genera should remain separate given the morphological overlap between them (Olsen et al. 1998, fig. 16). Getty (2005) also 


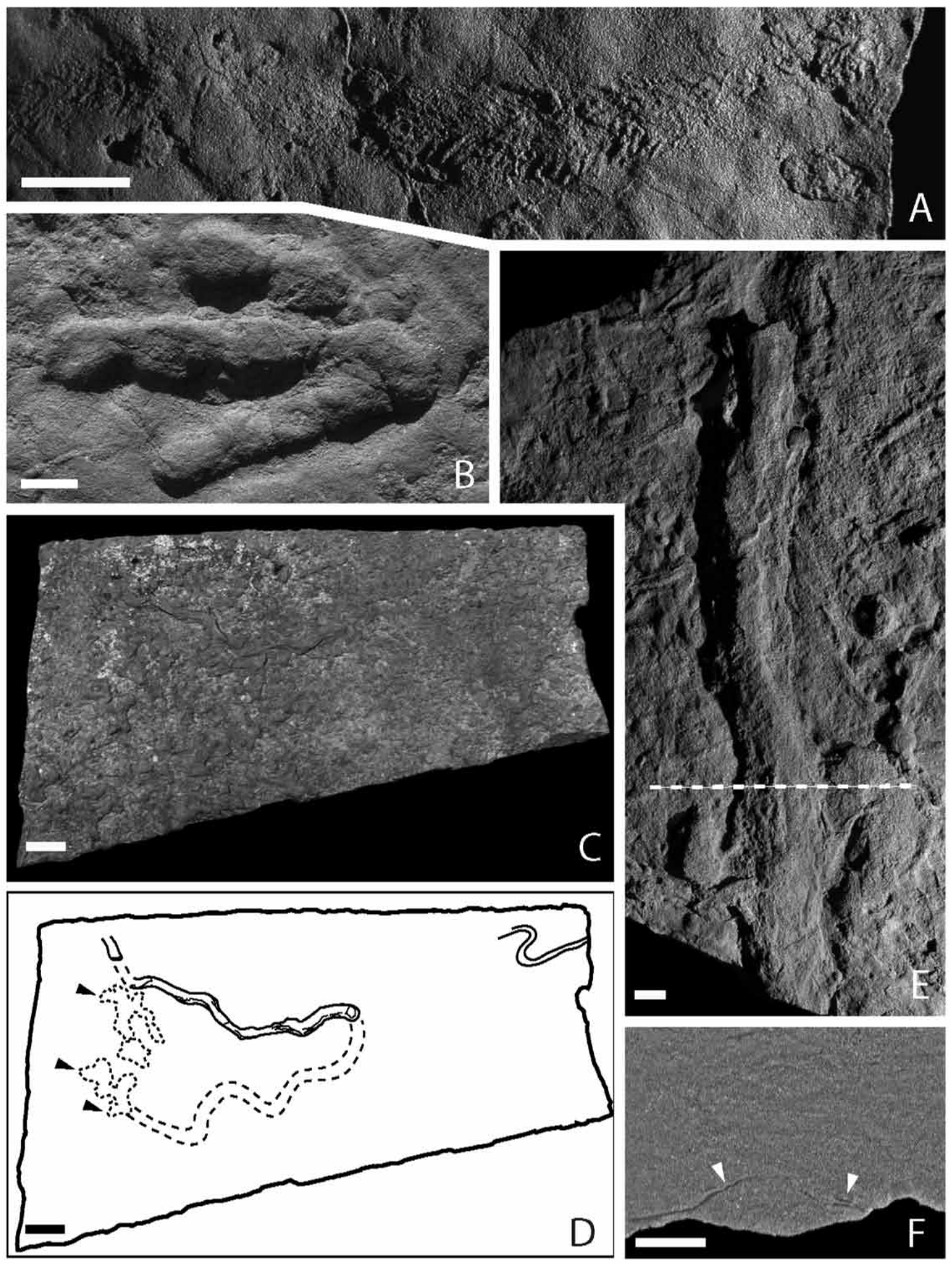

Fig. 2. (A) Arthropod trackway cf. Pterichnus isp. cross-cut by several Skolithos. (B) Eubrontes cf. gracilis dinosaur footprint. (C) An in-situ, heavily-bioturbated slab showing two Palaeophycus tortuosus (Hall 1852). (D) Simplified line drawing of slab illustrating burrow morphology. Dashed lines indicate where the burrow has spalled away from the rock. Arrows show potential distal burrow swellings, but the material is too poorly preserved to call these galleries. (E) Cross-sectioned Palaeophycus specimen; line of cross-section in F shown by dashed line. Total length of burrow $=22.4 \mathrm{~cm}$. F) Palaeophycus cross-section, showing the lensoid shape and mud laminae (arrows). All photos are of bed soles. Scale bars: A,B, E, andF, = $1 \mathrm{~cm} ; \mathrm{C}, \mathrm{D}=10 \mathrm{~cm}$. 
noted theropod tracks with a mix of morphological characteristics from the East Berlin Formation of Holyoke, Massachusetts, and Rainforth (2005) placed Grallator into synonymy with Eubrontes, the latter being the senior name (Olsen et al. 1998). Some figured specimens of Eubrontes gracilis (e.g., Rainforth 2005, figs. 2.25 c-e) are similar to the Hoover Quarry specimen in that they have a shorter digit III, higher angle of divarication, and a digit III that is relatively longer than digit II. Thus we tentatively assign this specimen to Eubrontes gracilis.

This well-preserved track occurs on a heavily bioturbated substrate (including Skolithos isp. and Planolites montanus) along with a second, poorly preserved track. Both are crosscut by minor bioturbation. The shallow depth of the well-preserved track suggests that the animal walked on a firm substrate (Gatesy et al. 1999; Getty 2005; Milan 2006). Alternatively, the specimen could be an undertrack; however, the lack of claw impressions suggests otherwise, since the claws impress the substrate deepest as the animal's weight is transferred to the toes during the step cycle. Indeed, claw impressions are commonly the only indication of deep undertracks (Rainforth 2005, p. 78; PRG personal observation). This leads to an interesting question: why are there no claw impressions in this otherwise well-preserved track? Unfortunately, the track is isolated, so whether the animal's left footprint was clawless is unknown.

The poorly developed mudcracks on this slab could indicate that subaerial exposure was brief, or that the underlying layer did not have sufficient mud to develop large cracks. These two footprints represent the youngest known occurrence of dinosaur ichnites in the Newark Supergroup (P. Olsen, personal communication, 2007).

\section{Ichnogenus Palaeophycus Hall, 1847}

Palaeophycus tortuosus Hall, 1852

(Figs. 2C-F)

non Palaeophycus tubularis sensu Pemberton and Frey 1982

DIAGNOSIs: Smooth, unornamented, gently curved to highly sinuous, thinly lined burrows of varying diameter.

DESCRIPTION: Subcylindrical, vertically compressed, curved to highly sinuous thinly lined burrows with few or no straight segments. Burrows parallel with, or slightly inclined to bedding, pinching toward sides, preserved in convex to irregularly concave hyporelief on bed soles, and internally within slabs in full relief. Linings smooth, without external ornamentation, composed of very finely laminated mud or clay. Burrow fills similar to matrix, but internal horizontal laminae are present. Diameter of burrows varies from 1 to $2.5 \mathrm{~cm}$, with significant variation in width of individual burrows; lengths from $5 \mathrm{~cm}$ to $>75 \mathrm{~cm}$. Collapse features present, no branching was observed.

REMARKs: Palaeophycus was erected by Hall in 1847 and originally interpreted as a plant fossil. In Hall's 1852 description of Palaeophycus tortuosus, he was still labouring under that interpretation, defining the ichnospecies as: "Stems or branches rounded, tortuous, frequently bifurcating; surface smooth and glossy. This species is a branching one ... The branches are often twisted or bent in zigzag forms, probably from pressure" (Hall 1852, p. 6). Presumably Hall possessed specimens that branched or interpenetrated, but the specimen figured in his 1852 book does not show branching. Nevertheless, Hall provided a clear basis by which to distinguish this form from the other species of Palaeophycus when he noted the twisted and bent "branches".

More recently, Pemberton and Frey (1982) examined the 54 "ichnospecies" of Palaeophycus, found that only 17 were truly representative of the ichnogenus, and concluded that these could be assigned to just five ichnospecies: Palaeophycus alternatus, Palaeophycus heberti, Palaeophycus striatus, Palaeophycus sulcatus, and Palaeophycus tubularis. Among their suggestions, Pemberton and Frey synonymized Palaeophycus tortuosus with Palaeophycus tubularis because they observed no specimens with a distinct meandering morphology. However, they suggested that Palaeophycus tortuosus might be re-evaluated if new specimens were found that demonstrated "a consistent morphological departure" from Palaeophycus tubularis.

In addition to the specimens described here, other workers have noted sinuous Paleophycus. Gierlowski-Kordesch (1985) described meandering forms from the East Berlin Formation, but assigned the specimens to Palaeophycus tubularis while noting (p. 93) "A minor problem with the Palaeophycus assignment is the burrow morphology. It is slightly more sinuous than usually described ... but no limits on sinuosity have been set". Other examples of large $(>40 \mathrm{~cm}$ length) sinuous Palaeophycus occur in the Turners Falls Formation of the Deerfield Basin. Additionally, Metz (1996, p. 121, fig. 3F) figured a meandering Palaeophycus that lacks straight segments; it is very similar to the meandering forms described herein, and we suggest that it be assigned to Palaeophycus tortuosus.

The clear morphological disparity in the amount of curvature between sinuous forms of Palaeophycus and those that are gently curving to mostly straight demonstrates a clear ethological distinction. Thus, we reject the synonymy of Palaeophycus tortuosus with Palaeophycus tubularis.

In addition to the distinctly curved to meandering morphology of Palaeophycus tortuosus, burrow branching may occur according to Hall's (1852) original description. However, systematic branching is not required, nor was any branching identified in the studied or previously published material (Hall 1852; Gierlowski-Kordesch 1985; Metz 1996).

An interesting set of features to note on the large Palaeophycus tortuosus slab shown in Figs. 2C, D are the poorlypreserved bulbous structures at the end of the large sinuous burrow. These features appear to be part of the original burrow, and display a swelling that could be consistent with a gallery-like structure at the distal termination of the burrow. Unfortunately, these structures are too poorly preserved to assess whether they are part of the burrow system, or separate structures that overprint it. Lateral pinching of the burrow is 

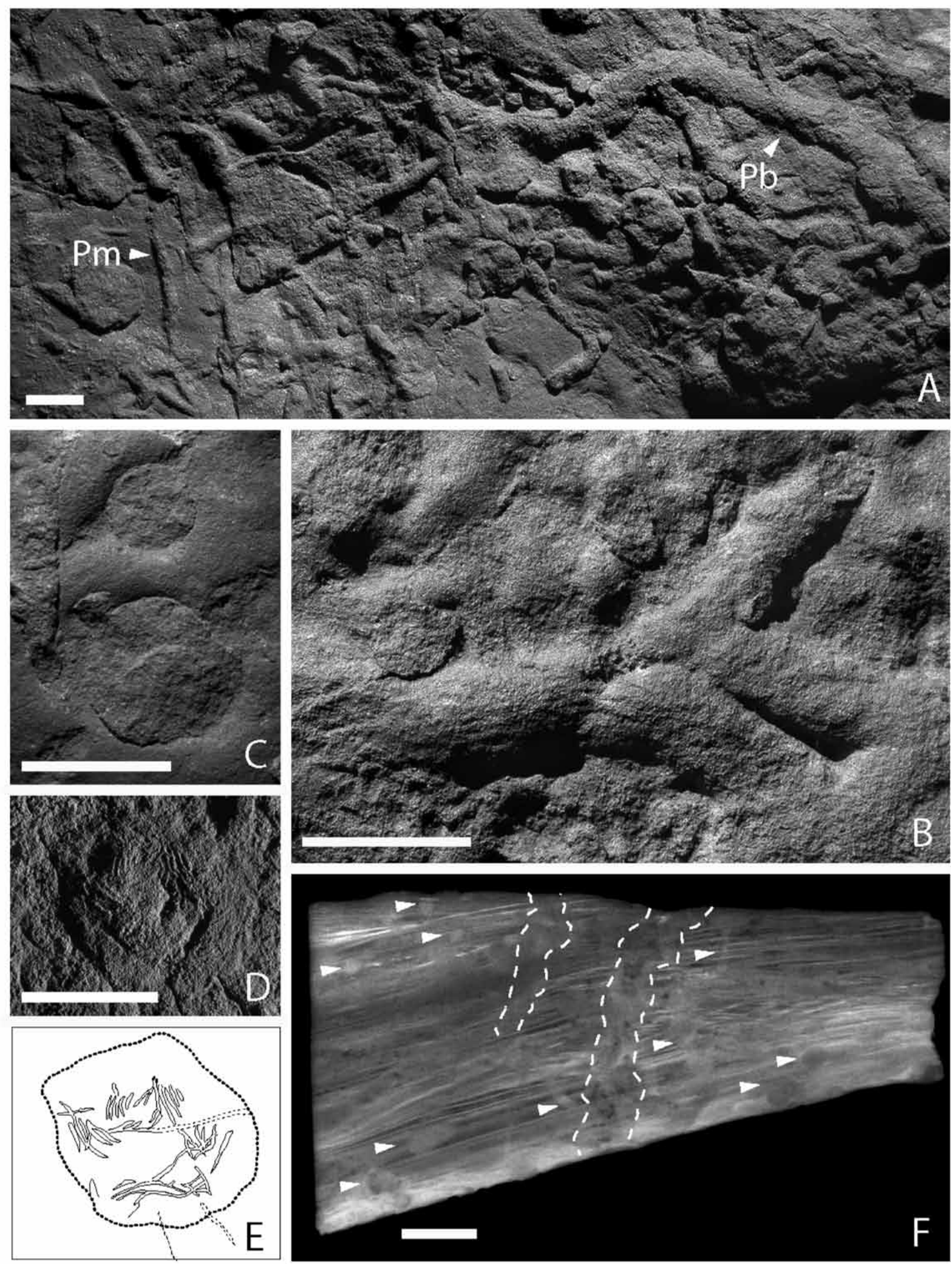

Fig. 3. (A) Planolites, including Planolites beverleyensis $(\mathrm{Pb})$ and Planolites montanus $(\mathrm{Pm})$. (B) Scoyenia cf. gracilis - note the fine longitudinal striations that are diagnostic of Scoyenia. (C) Skolithos isp. (D) Skolithos burrow termination on bed sole displaying delicate scratch marks. (E) Camera lucida drawing of D. (F) X-radiograph of Skolithos (outlined) on $\sim 1 \mathrm{~cm}$ thick slabbed showing disruption of cross-bed laminae, sole of bed is at the top. Note the intense bioturbation (subhorizontal to horizontal burrows indicated by arrowheads). All images except $\mathrm{F}$ are of bed soles. All scale bars $=1 \mathrm{~cm}$. 
likely due to collapse and compaction of an originally tubular or ovate structure.

In cross-sections of the burrows, fills are primarily structureless, although thin horizontal sandy laminae separated by clay drapes are present on some burrow floors (Fig. 2F). The sediment in the surrounding rock shows relatively little structure (Figs. 2E-F). The compositional similarity of the surrounding rock to the "structureless" burrow fill is largely attributed to passive infill of an open burrow system. The laminae on the burrow floor were likely produced by passive sedimentation in an abandoned burrow system. This would require low flow regimes, because rapid sedimentation would choke the burrow entrance, while more distal areas of the burrow would remain unfilled. Alternatively, the laminae may have been produced as sediment gradually accumulated on the floor of the open burrow and was subsequently compacted by movement of an animal through the burrow system.

Palaeophycus is interpreted as the domichnion of an infaunal invertebrate. Insects are thought to have produced Palaeophycus in terrestrial settings (Häntzschel 1975; Gierlowski-Kordesch 1985; Buatois and Mangano 1993).

\section{Ichnogenus Planolites Nicholson, 1873}

Planolites beverleyensis Billings, 1862

(Fig. 3A, arrowed as Pb)

DESCRIPTION: Unlined, mostly cylindrical, straight to meandering, smooth to slightly textured burrows, undulose, parallel with, or at an acute angle to the bedding surface, preserved in convex and concave hyporelief and epirelief on bed soles and surfaces.

Usually occur in masses showing burrow cross-overs, size range $5.9-10 \mathrm{~mm}$ in diameter, with an average of $8.6 \mathrm{~mm}$. Exposed lengths are highly variable, to $25.5 \mathrm{~cm}$.

Planolites cf. montanus Richter, 1937

(Fig. 3A, arrowed as Pm)

DESCRIPTION: Unlined, mostly cylindrical, straight to meandering, smooth to highly textured burrows, undulose, parallel with, or at acute angles to bed surfaces, preserved on bed soles and surfaces in convex and concave hyporelief and epirelief. Infill shows irregular structure differing only slightly in colour and sorting from surrounding rock. Overlapping and interpenetration of burrows is fairly common, branching was not observed. Exposed burrow length is variable - usually quite short, with the burrows emerging onto the bedding plane from overlying or underlying layers. Burrows range from $>2 \mathrm{~mm}$ to $\sim 5 \mathrm{~mm}$ wide with a distinct mode around $3 \mathrm{~mm}$, exposed lengths to $10 \mathrm{~cm}$.

REMARKs: Planolites represent the feeding trace (fodichnion) of a mobile infaunal deposit feeder. Smaller size and a more meandering course distinguish Planolites montanus from the larger diameter, straighter Planolites beverleyensis (Pem- berton and Frey 1982). The burrow fill may differ slightly in both colour and texture from the surrounding matrix, possibly due to the extraction of organic residues by the tracemaker (Pemberton and Frey 1982). Burrows are more circular in cross-section due to active backfill, in contrast to the commonly compressed Palaeophycus, which is passively filled. Some Planolites beverleyensis exhibit variable burrow diameters along their lengths. Barring compactional differences, this variation could indicate peristaltic motion of the tracemaker.

Both Planolites and Palaeophycus range in age from the Ediacaran to Holocene (Häntzschel 1975) and are found in almost every depositional environment (Pemberton and Frey 1982), so their usefulness as paleoenvironmental indicators is limited. However, in continental settings, most workers report Planolites in lacustrine, floodplain, or channel facies; thus, standing water (or at least fully saturated substrates) seems to be a necessity for the Planolites tracemaker (Gierlowski-Kordesch 1991; Pickerill 1992; Buatois and Mangano 1993; MacNaughton and Pickerill 1995; Metz 1996; Keighley and Pickerill 2003; Gillette et al. 2003; Melchor 2004). The Planolites producer may be a variety of vermiform animals, perhaps polychaetes (Pemberton and Frey 1982), although arthropods, including insect larvae, are more likely producers in continental settings (Buatois and Mangano 1993). A slightly irregular and unpatterned texture is seen on burrow surfaces in many examples from the Hoover Quarry. This is likely caused by weathering, as the talus piles from which the present material was collected have been exposed at the surface for over 80 years.

\section{Ichnogenus Scoyenia White, 1929}

\section{cf. Scoyenia isp.}

(Fig. 3B)

DESCRIPTION: Slender, cylindrical to subcylindrical, straight to curved, unbranched bedding plane-parallel burrows. Burrow surfaces display faint, evenly spaced, parallel longitudinal striations; where burrow infills are visible, faint meniscae are present. Burrows are 6-6.2 $\mathrm{mm}$ wide, $3-4.9 \mathrm{~cm}$ long, and are preserved in convex hyporelief on bed soles.

REMARKS: Only two burrows from the Hoover Quarry display the longitudinal striations characteristic of this ichnogenus. The burrow infill of these two specimens is not readily apparent. However, many co-occurring burrows of similar width that do not preserve longitudinal striae do preserve faint internal meniscae. Because no single specimen preserves both the external longitudinal ornament and the internal meniscate infill, these burrows are assigned to cf. Scoyenia. Lack of striae on these samples may be due to poor preservation resulting from exposure, or may be a result of sediment coarseness (Frey et al. 1984). Soil moisture conditions likely also play a role in the preservation of the longitudinal ornamentation. Hasiotis (2002), and Hasiotis and Bown (1992), suggested that this trace fossil is an indicator of high soil moisture conditions (ap- 
proaching $40 \%$ ), and soil conditions similar to those found in lacustrine environments.

This trace is also a useful climatic indicator, occurring in wet, monsoonal, lacustrine, and wet portions of dry seasonal climate deposits (Hasiotis 2002). In Hoover Quarry material, both examples of Scoyenia gracilis occur in conjunction with desiccation cracks, indicating a periodically emergent environment.

These trace fossils have been interpreted as feeding and/ or domichnial traces of coleopteran (beetle) larvae, (Hasiotis 2002); decapod crustaceans (crayfish burrows), (GierlowskiKordesch 1985; Olsen 1988); and arthropods of unknown affinity (Frey et al. 1984). Fossil beetle eleytra (wing covers) have been found in siltstone horizons of the Portland Formation, and beetle larvae of the species Mormolucoides articulates have been found in rocks of the approximately coeval Turners Falls Formation (Lull 1953; Olsen 1988; McDonald 1992).

\section{Ichnogenus Skolithos Haldeman, 1840}

Skolithos isp.

(Figs. 3C, F; 4A, B)

DESCRIPTION: Circular to elliptical, cylindrical to subcylindrical, vertical to slightly inclined, unlined, unbranched burrows 2.8 to $19.1 \mathrm{~mm}$ in diameter. Burrow walls sharply truncate surrounding matrix and may vary in diameter within individual burrows. Infill irregular, from vuggy to well filled, with fill lithology differing from that of the host rock. Bedding plane terminations are concave, planar, or convex. Funnel-shaped surface terminations are not present. Burrows preserved as concave or convex hyporelief and epirelief.

REMARKS: Simple tubular vertical burrows occur in both marine and continental deposits. Their generalized morphology likely reflects similar life habits rather than closely related makers. Many animals construct simple lined or unlined vertical burrows in a wide range of environments, from insects (Bown 1982) and spiders (Schlirf and Uchman 2005) in continental firmground and overbank deposits, to tube-building annelids and phoronids (Alpert 1974) in marine settings. The occurrence of Skolithos is likewise quite widespread, and alone is not a good paleoenvironmental indicator.

Skolithos from the Hoover Quarry routinely cut through multiple bedding planes; lower terminations are almost always absent and upper terminations are also rare. Thus only minimum estimates of burrow depth $(1.4$ to $16 \mathrm{~cm})$ can be obtained. On a few slabs, hemispherical burrow projections occur, predominantly on soles. No funnel-shaped burrow entrances were observed on bed tops, but on one slab small circular depressed areas are present on a sole adjacent to burrow openings (Fig. 4A). These depressions represent mounds on the original underlying bed and are in close proximity to the burrows on the slab; they are hypothesized to represent sediment that was excavated by the tracemaker and then deposited adjacent to burrow entrances. X-radiographs of slabs cut $1-1.5 \mathrm{~cm}$ thick show that individual burrows vary significantly in diameter, possibly due to compaction (see Fig. 3F). Shape varies, from burrows with a straight, nearly constant diameter to those that are wavy, irregular or zigzag. Burrows are most typically oriented $90^{\circ}$ to bedding but can be moderately steep, with burrow orientations relative to bedding of between $50^{\circ}$ (Fig. 3F) and $73^{\circ}$ (Fig. 4B). Skolithos burrows from the Hoover Quarry frequently occur in conjunction with desiccation cracks, and burrow infills commonly show a vuggy texture with large voids preserved, the latter is an indication that the burrows were constructed in a subaerial environment where sediments were sufficiently cohesive that burrow collapse did not occur. Skolithos burrows from the Hoover Quarry can be distinguished from Planolites by their larger overall diameter, their rounder cross-section, the commonly vuggy nature of their infill, and their nearly vertical orientation.

Hoover Quarry Skolithos are quite variable in diameter, from 0.28 to nearly $2 \mathrm{~cm}$. Burrow size distribution (Fig. 4C) exhibits weak bimodal distribution, with the major mode occurring in the 8 to $10 \mathrm{~mm}$ range, and a minor mode in the 4 to $6 \mathrm{~mm}$ range. The distribution may indicate different species constructing the burrows, different types of burrow-producers, or different ontogenetic stages of a single species.

Skolithos burrows from Hoover Quarry material commonly cross-cut one another, but only in extremely rare cases do other trace fossils cross-cut Skolithos burrows. However, they are cut by, and cross-cut, desiccation cracks. These cross-cutting relationships suggest that either the Skolithos burrows were constructed after water-dependent animals could no longer occupy this area, or that the assemblage declines in diversity because fewer traces could be preserved in drier sediments.

\begin{tabular}{c}
\hline Incertae sedis \\
\hline vertical burrow lower termination \\
aff. Skolithos \\
$($ Figs. 3D, E)
\end{tabular}

DESCRIPTION: Circular (14.7 mm wide), unlined, slightly convex vertical burrow lower terminus preserved in convex hyporelief on bed sole. Infill similar in colour and texture to surrounding matrix; burrow margin unsharp. A series of five to six discrete sets of parallel, semi-parallel, overlapping, or Y-shaped convex striations is arranged in various orientations around the periphery of the burrow. Each scratch set contains three to six individual convex scratches. Individual scratches $<1 \mathrm{~mm}$ wide, $1.38-2.69 \mathrm{~mm}$ long. Scratch termini rounded or tapering to sharp point.

REMARKS: This specimen is the only example known from the Portland Formation of this kind of sculpted burrow termination. The burrow termination is capped by fine sand at the bottom of a vertical tube (Figs. 3D, E). The sets of parallel to overlapping scratches preserved on the bottom of this burrow are interpreted here as having been produced by the tracemaker, possibly through interaction of limbs, caudal appendage(s), or setae with unconsolidated fine sediments on the burrow floor. 

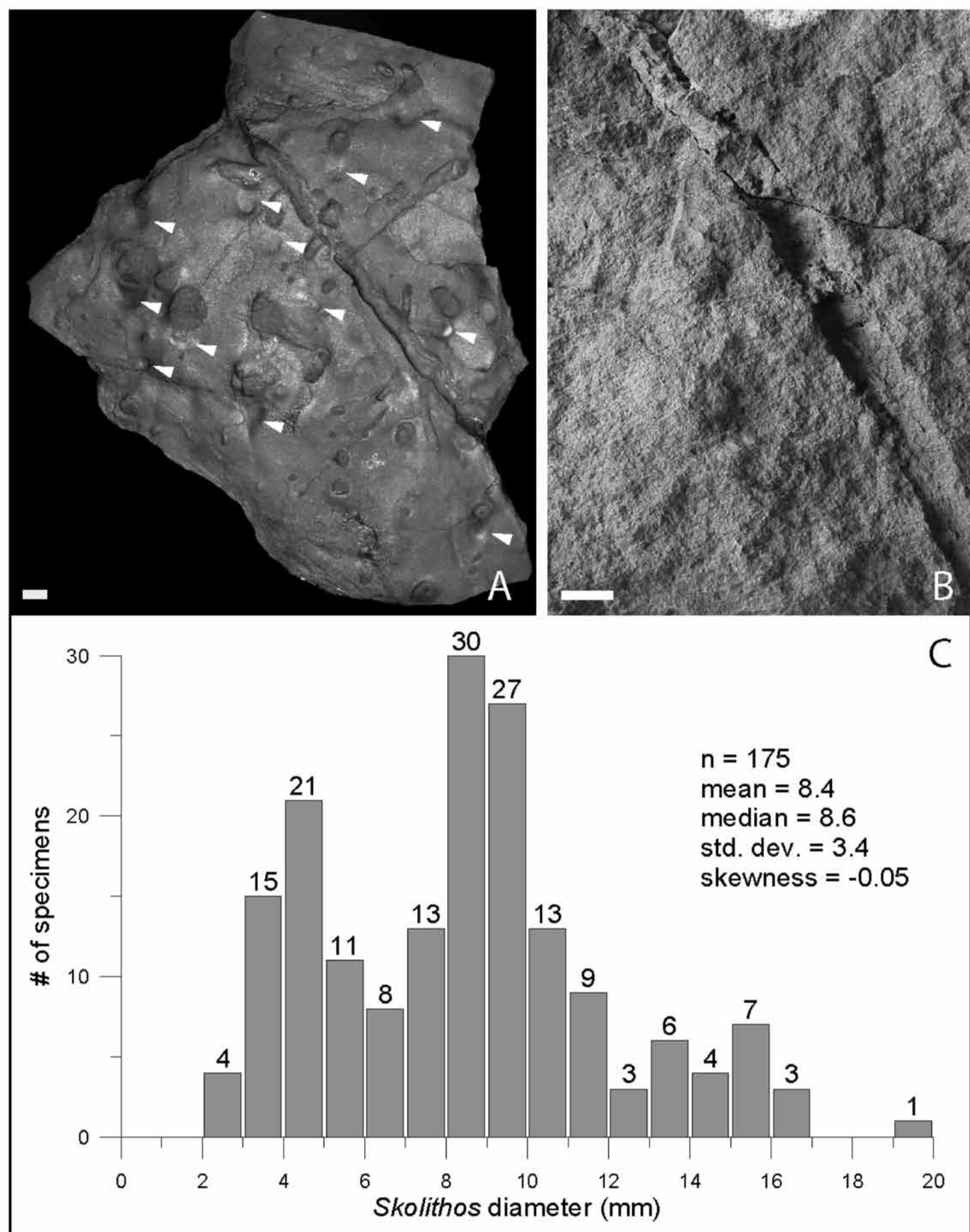

Fig. 4. (A) Skolithos-bearing bed sole showing depressions (arrowheads) interpreted as mounds of sediment displaced by the tracemaker on the original surface. (B) Side view of a Skolithos with its fill partially preserved. (C) Diameters of 175 measured Skolithos from six slabs. On small slabs, every burrow was measured; on larger slabs, burrows within a randomly selected $20 \times 20 \mathrm{~cm}$ area were measured. See text for discussion. All scale bars $=1 \mathrm{~cm}$. 
This type of striated vertical burrow lower termination has been previously attributed to Skolithos sp. exclusively from nonmarine deposits (Bromley and Asgaard 1979; Schlirf et al. 2001; Schlirf and Uchman 2005). Schlirf and Uchman (2005) questioned whether striated or scratched lower termini in Skolithos burrows might be a diagnostic feature in continental forms. Thus it is unclear if simple unlined vertical burrows that display ornamentation of any kind may be attributed to the ichnogenus Skolithos. The emended diagnosis given by Schlirf and Uchman (2005) does not mention ornament: "Unbranched, vertical to steeply inclined, straight to slightly curved, cylindrical to subcylindrical, lined or unlined structures, with or without funnel-shaped top. Wall distinct or indistinct, smooth to rough, some specimens annulated; fill massive; burrow diameter in some individuals slightly inconstant.” However, this diagnosis makes no mention of lower burrow terminations, which some authors note are infrequently preserved (e.g., Bromley and Asgaard 1979; Gierlowski-Kordesch 1985). In Portland Formation sandstone, Skolithos burrows almost never terminate at bed interfaces, but continue through them. Thus, nearly all vertical burrows terminate within sandstone beds. Vertical burrows can be characterized in cross-section by slabbing and by $\mathrm{X}$-radiographs (Fig. 3F). Such techniques can show gross details of burrow structure, including within-bed burrow terminations (Fig. 3F, left side). However, fine-scale or delicate structures that might be preserved at bed interfaces, such as scratch marks, cannot be resolved using these imaging techniques.

Another burrow that commonly displays scratch-like external ornamentation is Scoyenia. However, this burrow termination differs from Scoyenia observed in Hoover Quarry material in that its orientation is perpendicular to bedding. Moreover, Scoyenia ornamentation is composed of raised scratches on burrow external walls, approximately longitudinal to burrows; in this burrow termination, scratches are internal to the burrow walls, and the orientation of scratch sets varies (see Figs 3D, E). Additionally, Scoyenia burrows are most commonly bedding-parallel (Gierlowski-Kordesch 1985; de Gibert and Saez 2009; Hubert and Dutcher 2010). Because of these differences, we prefer the interpretations of Bromley and Asgaard (1979), Schlirf and Uchman (2005), and Schlirf et al. (2001), and ally this trace with Skolithos.

Terrestrial arthropods that could have made this type of burrow include insects, particularly coleopterans, and their larvae (Bromley and Asgaard 1979; Hasiotis 2002; Schlirf and Uchman 2005).

problematic stellate structures

(Figs. 5A-C)

DESCRIPTION: Series of raised, radially-arranged, linear impressions, unevenly spaced and varying in length, width, and relief, that may or may not be oriented around a depressed central pore. Linear impressions confined to a semi-circular area that may be flat to somewhat depressed or bowl-shaped; impressions generally end in a sharply pointed distal termination, although blunt and semi-rounded terminations also occur.
Proximal origin of radiations vague, but in some examples linear impressions extend into the pore area. Rarely, semi-circular scratches are associated with these structures and cross-cut the radial impressions (Fig. 5C). These traces are preserved in convex hyporelief on bed soles as sand castings of mud drapes and have a diameter of 8 to $14 \mathrm{~mm}$; the width of individual striae range from $\sim 0.2 \mathrm{~mm}$ to $0.4 \mathrm{~mm}$.

These structures occur on mud or clay draped surfaces containing well-preserved raindrop impressions, Planolites montanus, Skolithos isp., and arthropod trackways. Thin sections revealed no significant compaction of the sediment grains immediately adjacent to the structures. This lack of compaction, along with the limited cross-cutting relationships observed (Fig. 5C, arrowed) indicates that these structures are primary and formed contemporaneously with other structures present on this slab.

REMARKS: The rock record is rife with discoidal and stellate structures, many of which have been described as trace or body fossils (e.g., Young and Hagadorn 2010; Hagadorn and Miller 2011). Although some such structures are biogenic, inorganic processes form most of them, and interpretations are rarely based on more than an analogy with modern organisms and processes (e.g., Reineck and Singh 1980; Ricci Lucchi 1995). To assess the origin of the Hoover Quarry stellate structures, we serially sectioned, X-rayed, and thin sectioned a suite of samples parallel and perpendicular to bedding, and compared these with similar modern and ancient structures. Potential interpretations of the Portland Formation stellate structures include:

- Crystal pseudomorphs. Evaporite crystal splays can produce radial structures (J. Warren, personal communication, 2007), and pseudomorphs preserved in local strata demonstrate that evaporates precipitated within the Hartford Basin (Gierlowski-Kordesch 1985; Demicco and Gierlowski-Kordesch 1986; Olsen et al. 1989). Magnesite, hydromagnesite, and gypsum precipitate under playa conditions, and latter can display a radial stellate morphology (Huene 1941). In many Hoover Quarry examples the radiating impressions are set in shallow parabolic depressions on bed soles, indicating that the original structures may have been mounded. Hydromagnesite can grow in such mounded masses of radiating crystals, but the crystals themselves are linear and quite thin, and no evidence of breakage is seen in our examples (Deer et al. 1992). Unlike evaporite crystals, the radiations in the Hoover Quarry structures closely follow the clay interface and do not penetrate into or rise above it. Furthermore, not all impressions are rigid linear bodies; some gently curve side to side along their lengths. Freezing water may also produce stellate ice crystals, which could leave patterns in soft sediment. However, the Hoover Quarry material exhibits concentric rings (e.g., Fig. 5A), and stellate ice crystals do not produce such features on crystal margins. Additionally, stellate ice crystals lack a central pore or shaft from which they emanate; such 

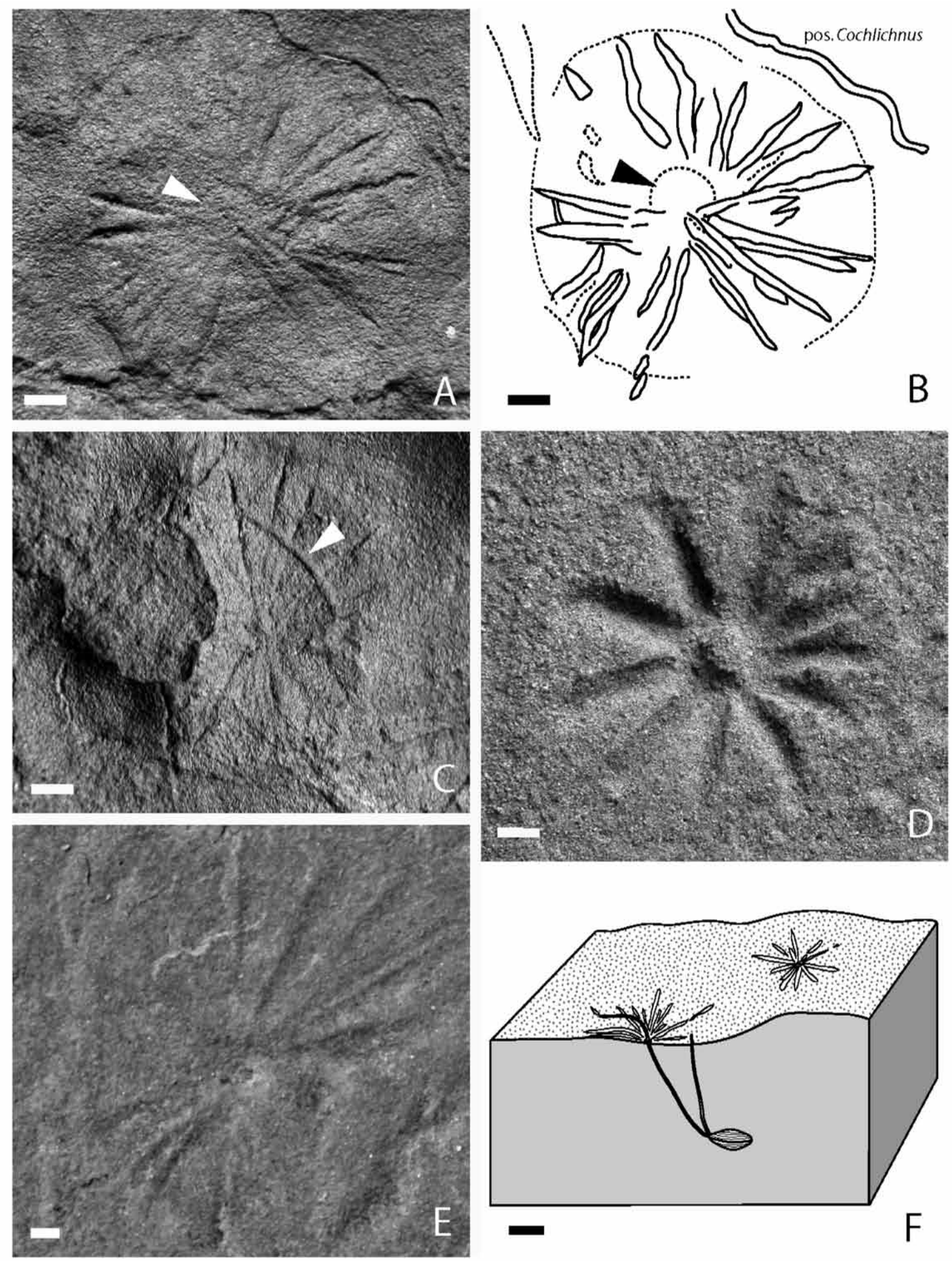

Fig. 5. (A) Stellate structure on bed sole showing radial morphology with distally pointed terminations and central "pore" (arrowhead). (B) Camera lucida drawing of A. (C) Stellate structure on bed sole showing cross-cutting relationships with a small burrow (arrowhead). (D) Surface-produced structure made by impressing a model horsetail into wet, muddy sediment. The structure is consistent in relief and basic morphology to the stellate fossils. (E), Palaeoscia floweri, upper surface showing radial morphology similar to that of the Hoover Quarry stellate structures. Photo courtesy of R. Webber. (F), possible mechanism for an animal trace origin of the stellate structures (see text for discussion). Block diagram showing the surface feeding behavior of infaunal bivalves, such as Macoma tenta (modified from Levinton 1971). Scale bars: A-E = $1 \mathrm{~mm} ; \mathrm{F}=1 \mathrm{~cm}$. 
structures are visible in Hoover Quarry specimens (e.g., Figs. 5A, C). Finally, an ice-origin for the Portland Formation structures also seems unlikely because stellate ice crystals commonly overlap and cross-cut one another (e.g., fig. 86 in Reineck and Singh 1980) yet none of the Portland Formation stellate structures overlap or crosscut one another. Overall, the sinuous nature of the striae, the presence of a centrally located pore, and the concentric rings seem inconsistent with a mineral-crystal origin for these structures.

- Dewatering or degassing structures. Sand volcanoes, such as Astropolithon, can produce arrays of dykes that radiate away from a central bulge (Pflüger 1999). However, these structures are generally larger than those from the Hoover Quarry, do not end in pointed distal terminations, and may require the presence of microbial mats for preservation (Sarkar et al. 2006). Spring pits or mound structures (Ricci Lucchi 1995) can also produce analogous structures, where vertically migrating fluids or gasses disrupt underlying bedding. However, Hoover Quarry examples are preserved as natural casts on the sole of overlying beds, so it is not possible to determine whether underlying sediment was disrupted.

- Fish scale or egg capsule impressions. Some fish scales bear radiating ridges that could produce molds if impressed into sediment. Hartford Basin fish include semionotids and diplurid coelacanths (Olsen et al. 1992; McCune 1996). Semionotids have heavy ganoid scales, but they are generally rhomboid in shape (Gemballa and Bartsch 2002; McCune 2004). Diplurid scales are ovate to ellipti$\mathrm{cal}$, may possess radiating ridges, and are covered in finer striae that terminate in a centrally located, occasionally raised focus (Schaeffer 1952). The ridges, however, are only present on parts of the scales overlapped by adjacent scales, and they are mostly parallel to one another (see Schaeffer 1952, fig. 12). All of these fish scales have pronounced concentric growth rings (A. McCune, personal communication, 2007), which were not observed in Hoover Quarry specimens. Finally, these fish are known from lake deposits, unlike Hoover Quarry fluvial deposits. Thus, it is unlikely that these structures represent the scales of any known Hartford Basin fish. Chimaeroid egg capsules occur in the Turners Falls Formation of the adjacent Deerfield Basin (Bock 1949). These capsules bear radiating linear ridges that originate in capsule's centre, but are different from Hoover structures in that they are much larger $(2.5 \mathrm{~cm}$ by $3 \mathrm{~cm})$ and have strong bilateral symmetry.

- Equisite (horsetail) whorl impressions. Equisites are known from early Jurassic sediments of the Hartford and Deerfield Basins (Olsen et al. 1992, p. 499), and the gross morphology of the stellate structures is similar to equisite whorls. Experimental work done with plastic equisite models, and observations of in-situ Equisetum hyemale, showed that analogous structures could be produced by impressing equisites into wet mud (Fig. 5D). The relief and morphology of these model-produced analogs are consistent with the stellate structures from the Hoover Quarry. Bockelie (1994) showed a cross-section of a modern equisite in growth position that could produce similar structures, with the radiations being analogous to roots and the central portion produced by underground parts of the stem (Bockelie 1994, fig. 7.7). A seasonal flood depositing sand over equisites in growth position also could form similar structures. We cannot confirm or falsify an equisite origin because we do not have part-counterpart specimens of Hoover Quarry stellate structures. However, given the presence of small-scale carbonaceous and coalified plant material in this facies (Olsen 1988), one would expect to find coalified or carbonaceous shaft-like structures under the central boss of the Portland stellate specimens if they had an equisite origin.

- Seed impressions or other botanic origin. Botanical structures with a roughly similar outline, size, and very general morphology occur in the sedimentary units of the Hartford Basin (Cornet and McDonald, personal communication). For example, the dwarf shoots of "Conanthus hystrixipinus" possess distally pointed lobe terminations, and winged seeds bear stellate-like surface patterns. Reproductive structures of this species produce digitate ten-lobed seed scales, which likely functioned as helicopter-like diaspora (Cornet and McDonald, personal communication). Such seeds might form impressions as they are deposited onto a wet, mud- or clay-draped surface. However, the preservation of the Hoover Quarry stellate structures is inconsistent with such seeds because the central area is preserved as a concave cast, whereas a seed should produce a convex cast from its original concave mold (B. Cornet, personal communication, 2007).

- Palaeoscia floweri. These are structures first described by Caster (1942) from Ordovician marine coquinas of Ohio (Fig. 5E), and originally interpreted as porpitid siphonophores. Osgood (1970, p. 397) re-examined the structures, and interpreted them as "sweep marks of an eroded [agglutinated] tube", based on the perfectly circular outlines and concentric rings, as well as the structure of the central pore's rim, numerous radial grooves, irregularity of concentric arcs, and the planed-off appearance of some arcuate features. However, sectioning of these Ordovician structures failed to show any tube-like structure, nor was any evidence of a tube or stem found in any of the additional 23 specimens that were interpreted as sweep marks.

The similarity in both size and shape of the central stellate portion of Palaeoscia floweri to the structures in question is remarkable. The diameter of the central portion of Palaeoscia floweri is consistent with the di- 
ameters observed in Hoover Quarry stellate structures. The number of radiations and the terminations are also similar. Palaeoscia floweri is preserved in concave epirelief, whereas the stellate traces from the Hoover Quarry are convex hyporelief. The central pore (when present) is roughly conical in shape, and is better developed in Palaeosciafloweri. The central "pore" in both is concave, thus the difference in relief is a distinctive feature. No scratch circles are associated with the Hoover Quarry structures. $\mathrm{X}$-radiographs and photomicrographs of slabbed and thin-sectioned Hoover Quarry specimens show no evidence of a central "shaft", but they are thus far known only from the soles of overlying beds, so the lack of a central shaft is not problematic.

- Animal produced trace fossil. A number of stellate trace fossils are known (e.g., Asteriacites Schlotheim 1820; Dactyloidites ottoi Geinitz 1849; Radiichnus staszici Karaszewski 1973), but none are very similar to the Hoover Quarry structures, and most are from marine settings. Modern bivalve mollusk feeding traces produced by Scrobicularia plana and Macoma tenta are quite similar in morphology to the Hoover Quarry stellate structures, but are larger in scale (Levinton 1971). They are produced as the buried bivalves protrude their siphons to the surface to feed (Fig. 5F). The commonly well-defined central pore or shaft in the material from the Hoover Quarry is consistent with an animal everting a proboscis/siphon onto the surface for feeding, and the radial, rarely overlapping impressions could represent scraping of the adjacent sediment surface. Unfortunately, because none of the beds that underlie the stellate structures are available for sectioning or examination, this hypothesis is currently untestable. Unio bivalves are known from the Portland Formation, but unioid bivalves lack the necessary anatomy to produce such traces (Good 2004).

Based on the small number of specimens available, their preservation as casts, and their unusual morphology, these stellate structures are placed in open nomenclature. Without counterpart specimens, we cannot falsify any of the aforementioned hypotheses for genesis of these structures. If they are inorganic, a scratch circle origin seems most plausible; if they are organic, botanic or proboscis-scratch origins are favoured.

Interestingly, morphologically similar stellate structures (Fig. 6) commonly occur in the Permian Maroon Formation of Colorado (S. Voigt, personal communication 2011). Based on the lithology, sedimentary structures, and trace fossils, the depositional environment of the Maroon Formation in which stellate structures occur is likely an alluvial plain with shallow, laterally extended channels (Voigt et al. 2005; S. Voigt personal communication 2011). Although the mode of production of these structures is not yet known, they are notable because they occur in similar facies as the Portland Formation stellate structures.

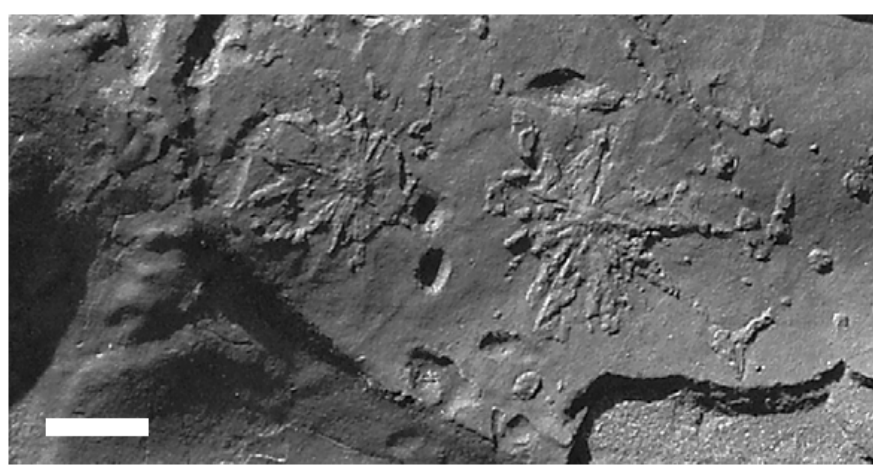

Fig. 6. Stellate structures from the Maroon Formation of Colorado, which are morphologically similar to those of the upper Portland Formation. Photograph courtesy of S. Voigt.

\section{Other fossils}

\section{Stegomosuchus longipes Emerson and Loomis 1904}

(Figs. 7A, B)

Very little vertebrate skeletal material has been recovered from the Hartford Basin, with a few exceptions, including Stegomosuchus longipes (Fig. 7A), a small plated crocodylomorph (see Emerson and Loomis 1904; Lull 1953; McDonald 1992). Stegomosuchus longipes was discovered about ten feet below the surface of the Hoover Quarry (then known as the Hines Quarry) in 1897 in a layer of dense red sandstone that was being removed to access the softer material used commercially as building stone (Emerson and Loomis 1904). The lithology of the stone encasing Stegomosuchus longipes is nearly identical to that of the present study.

Two blocks are preserved, the lower block containing the actual remains of the animal, and the overlying block that preserves a mold of the animal. The upper surface of the top block and the lower surface of the bottom block are heavily bioturbated by Planolites and Skolithos (Fig. 7B). Interestingly, bioturbation is much greater on the top surface of the upper block than on the sole of the lower block; no burrows are observed penetrating to the horizon containing the skeletal remains. One potential explanation for these observations is that less bioturbation occurred on the sole of the lower block due to desiccation. Alternatively, the time available for colonization by burrowing animals may have been limited by the rapid deposition of the thick sand bed that interred Stegomosuchus longipes, and surface conditions were then reestablished that once again allowed bioturbators to begin to construct burrows. The intact vertebrate remains suggest that the invertebrate tracemakers did not feed directly on carcasses, or that the carcass was out of their reach.

Stegomosuchus longipes has been interpreted as an agile landdwelling crocodilian (Emerson and Loomis 1904; Lull 1953; Carroll 1988 and references therein), and is considered the probable tracemaker of the ichnogenus Batrachopus (Lull 1904, 

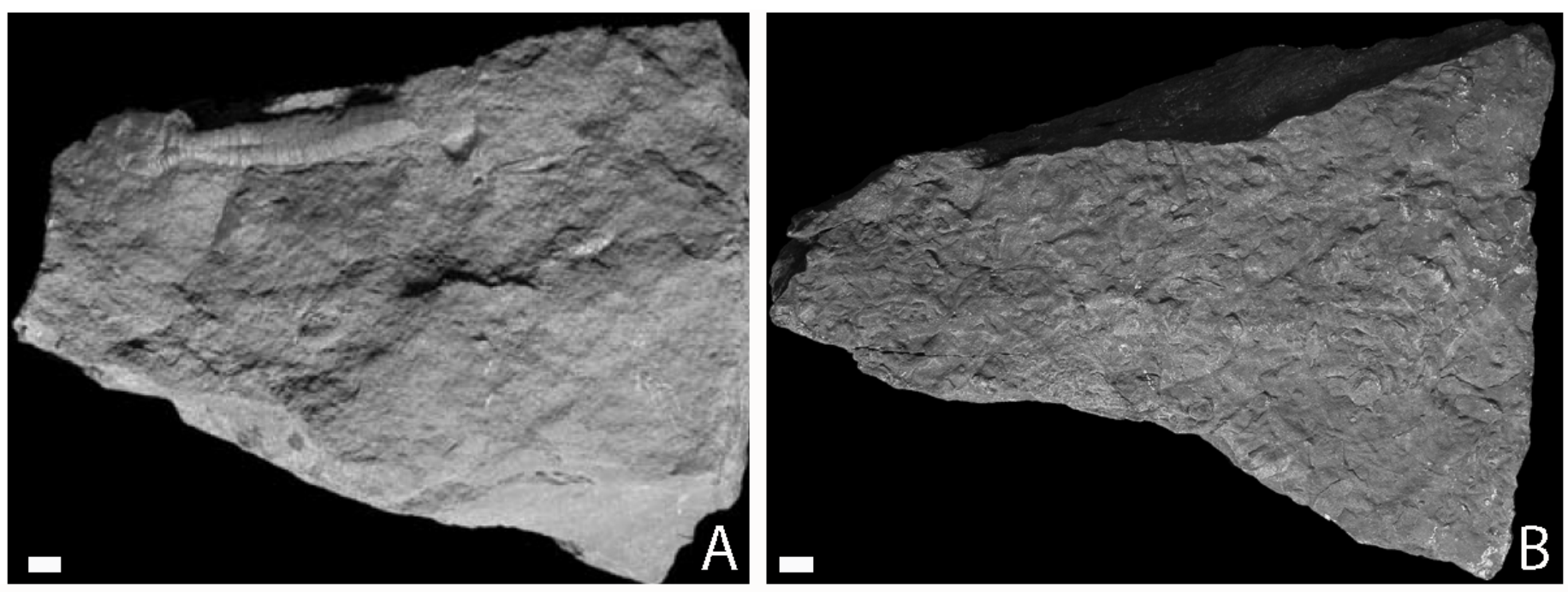

Fig. 7. (A) Top view of lower block containing Stegomosuchus longipes, a crocodylomorph recovered from the Hoover Quarry in 1897. Note the absence of trace fossils in the horizon containing the skeleton. (B) Upper surface of the upper block of the Stegomosuchus longipes specimen. Note the extensive bioturbation similar to other Hoover material (e.g., Figs. 2C, $3 \mathrm{~A}$ ). Scale bars $=1 \mathrm{~cm}$.

1953; Olsen and Padian 1986; McDonald 1992). Although no trackways were found at the site, Batrachopus trackways are fairly common throughout the Hartford and Deerfield Basins (Olsen and Padian 1986). The presence of Stegomosuchus longipes along with Eubrontes footprints and invertebrate trackways and burrows suggests a diverse assemblage of animals at this site.

\section{PALEOENVIRONMENTAL INTERPRETATIONS}

Although only two specimens confidently attributable to Scoyenia were recovered from the Hoover Quarry, the overall assemblage of this site is assigned to a Scoyenia-Skolithos composite ichnofacies based on criteria outlined by Frey and Pemberton (1984), Buatois and Mangano (1995), and Keighley and Pickerill (2003). Currently, the Scoyenia ichnofacies is considered representative of moist or wet fine-grained sediments in shallow, low energy, aquatic deposits that are either periodically exposed to air, or are in low areas periodically inundated by water (Frey et al. 1984; Frey and Pemberton 1984; Buatois and Mangano 1995).

Although the complete paleoenvironmental context of the Hoover Quarry is unknown because it is submerged, some general conclusions can be drawn from the material collected. The occurrence of invertebrate trace fossils from the Hoover Quarry in association with dinosaur tracks and primary structures such as flaser bedding, raindrop impressions, desiccation cracks and asymmetrical ripples is consistent with very shallow aquatic, periodically emergent environments. The structure of some of the individual trace types is also consistent with fluctuations in water saturation. For example, specimens of Skolithos lack burrow linings, but have sharply delineated burrow walls, suggesting formation in cohesive substrates (Bromley and Asgaard 1979; Gierlowski-Kordesch 1985). In contrast, their infill is vuggy, which is consistent with filling in a dry, terrestrial environment where sediment compaction was minimal (Bromley and Asgaard 1979). Finally, the extensive bioturbation present in Hoover Quarry material suggests wet periods long enough for significant sediment modification to occur, as well as the availability of sufficient organic materials in the sediments to sustain a substantial population of burrowing deposit feeders.

Skolithos burrows are a common component in Hoover Quarry rocks, occurring in every slab examined. They commonly cross-cut each other and all other trace fossils in rocks in which they occur. However, other traces rarely cross-cut Skolithos. Together with their well-defined, yet unlined, burrow walls, this suggests that Skolithos burrows may have been constructed after other traces, perhaps indicating Skolithos tracemakers inhabited the locality after it had become inhospitable to other tracemakers, perhaps due to drying.

Such overprinting of traces characteristic of different ichnofacies has been recognized elsewhere. Keighley and Pickerill (2003) offered emended concepts for the Mermia and Skolithos ichnofacies, and in Carboniferous nonmarine rocks of eastern Canada, recognized ichnocoenoses that contained traces from both ichnofacies. In continental rocks from the Cretaceous of South Korea, Kim et al. (2005) also concluded that in some of their track bearing ichnocoenoses there were traces characteristic of the Mermia, Skolithos, and Scoyenia ichnofacies. These authors separated traces into "morphological groups" that themselves are characteristic of discrete ichnofacies, and used these groups to conclude that some of their assemblages represented composites of more than one ichnofacies (Keighley and Pickerill 2003; Kim et al. 2005). If the approach of these 
authors is applied to the Hoover Quarry assemblage, morphological groups VII (Palaeophycus, Planolites), VIII (Eubrontes cf. gracilis, Pterichnus), XII (cf. Scoyenia), and XIII (Skolithos) are present. Keighley and Pickerill's (2003) emended Scoyenia ichnofacies concept encompasses all of these, including vertical burrows (Skolithos). However, they noted that vertical burrows (group XIII) should be "of limited abundance" (Keighley and Pickerill 2003, p. 18). Considering the high abundance of Skolithos in Hoover Quarry rocks, Keighley and Pickerill's criteria further support a composite trace assemblage.

\section{CONCLUSIONS}

Each additional study of continental trace fossils offers the opportunity to refine our understanding of the facies boundaries and ethology of the tracemakers. In the present study, fluvial strata of the Lower Jurassic Portland Formation of the Hartford Basin were examined, and a suite of trace fossils belonging to a Scoyenia-Skolithos composite ichnofacies was identified. Cross-cutting relationships of burrows, such as the overprinting of the Skolithos-dominated assemblage over Planolites and Palaeophycus dominated surfaces indicates that animal communities changed with fluctuations in water saturation, and provides further evidence to support the transitional submergent-emergent nature of the Scoyenia ichnofacies. Sedimentary structures that occur with these trace fossils are internally consistent with this interpretation of the Scoyenia ichnofacies. Among the traces in this assemblage, winding and meandering Palaeophycus traces are notable in providing evidence for the retention of Palaeophycus tortuosus as a separate ichnospecies from Palaeophycus tubularis. Stellate structures are also notable, although their origin is enigmatic.

\section{ACKNOWLEDGMENTS}

JHC wishes to thank his parents, Annette and Joe, who ultimately made this contribution possible. We thank William Driscoll and Kevin Getty for invaluable field assistance including transportation to and from the quarry and for identification and collection of specimens. Brenda Hanke and Robert Webber (Cincinnati Museum Center) are thanked for photographs of type specimens, and Kate Wellspring is acknowledged for help with specimens in the Hitchcock Collection. We gratefully acknowledge advice from conversations and correspondence with: Richard Bromley, Bruce Cornet, Elizabeth GierlowskiKordesch, John Hubert, Amy Reed McCune, Robert Metz, Paul Olsen, Steve Sauter, and Don Wise. Sebastian Voigt kindly provided images of Maroon Formation stellate traces. We thank Jacob S. Benner, an anonymous reviewer, and the editorial staff at Atlantic Geology for helpful comments that improved an earlier version of this paper. This project was brought to the attention of PRG by William Driscoll of East Longmeadow, a retired science teacher who found the dinosaur footprints and catalyzed our research in the Hoover Quarry. The Mellon Foun- dation and the Department of Geosciences at the University of Massachusetts - Amherst are thanked for providing funding to support this project.

\section{REFERENCES}

Alpert, S.P. 1974. Systematic review of the genus Skolithos. Journal of Paleontology, 48, pp. 661-669.

Billings, E. 1862. New species of fossils from different parts of the Lower, Middle, and Upper Silurian rocks of Canada. In Palaeozoic fossils, volume 1. Geological Survey of Canada, pp. 96-168.

Bock, W. 1949. Triassic chimaeroid egg capsules from the Connecticut Valley. Journal of Paleontology, 23, pp. 515-517.

Bockelie, J.F. 1994. Plant roots in core. In The Palaeobiology of trace fossils. Edited by S. K. Donovan. The Johns Hopkins University Press, Baltimore, Maryland, pp. 177-199.

Bown, T.M. 1982. Ichnofossils and rhizoliths of the nearshore fluvial Jebel Qatrani Formation (Oligocene), Fayum Province, Egypt. Palaeogeography, Palaeoclimatology, Palaeoecology, 40, pp. 255-309. doi:10.1016/0031$\underline{0182(82) 90031-1}$

Bromley, R., and Asgaard, U. 1979. Triassic freshwater ichnocoenoses from Carlsberg Fjord, east Greenland. Palaeogeography, Palaeoclimatology, Palaeoecology, 28, pp.39-80. doi:10.1016/0031-0182(79)90112-3

Buatois, L.A., and Mangano, M.G. 1993. The paleoenvironmental and paleoecological significance of turbiditic lake ichnocoenoses from the late Carboniferous of the Paganzo Basin, Argentina. Comptes Rendus XII International Congress Carboniferous-Permian, 2, pp. 409-420.

Buatois, L.A., and Mangano, M.G. 1995. The paleoenvironmental and paleoecological significance of the lacustrine Mermia ichnofacies: an archetypal subaqueous nonmarine trace fossil assemblage. Ichnos, 4, pp.151-161. doi:10.1080/10420949509380122

Carroll, R.L. 1988. Vertebrate paleontology and evolution. Freeman, New York, NY, 698 p.

Caster, K.E. 1942. Two siphonophores from the Paleozoic. Palaeontographica Americana, 14, pp. 1-34.

Cirilli, S., Marzoli, A., Tanner, L., Bertrand, H., Buratti, N., Jourdan, F., and Bellieni, G. 2009. Late Triassic onset of the Central Atlantic Magmatic Province (CAMP) volcanism in the Fundy Basin (Nova Scotia): new stratigraphic constraints. Earth and Planetary Science Letters, 286, pp.514525. doi:10.1016/j.epsl.2009.07.021

Deer, W.A., Howie, R.A., and Zussman, J. 1992. An introduction to the rock-forming minerals. Second edition. Longmans, London. 712 p.

De Gibert, J.M., and Saez, A. 2009. Paleohydrological significance of trace fossil distribution in Oligocene fluvial-fan-to-lacustrine systems of the Ebro Basin, Spain. Palaeogeography, Palaeoclimatology, Palaeoecology, 272, pp 162-175. doi:10.1016/j.palaeo.2008.10.030

Demicco, R.V., and Gierlowski-Kordesch, E. 1986. Fa- 
cies sequences of a semi-arid closed basin: the lower Jurassic East Berlin Formation of the Hartford Basin, New England, U.S.A. Sedimentology, 33, pp.107-118. doi:10.1111/j.1365-3091.1986.tb00747.x

Emerson, B.K., and Loomis, F.B. 1904. On Stegomus longipes, a new reptile from the Triassic sandstones of the Connecticut Valley. American Journal of Science, 17, pp. 377-380. doi:10.2475/ajs.s4-17.101.377

Frey, R.W., and Pemberton S.G. 1984. Trace fossil facies models. In Facies models. Second edition. Edited by R.G. Walker. Geoscience Canada, Reprint Series 1, p. 189-207.

Frey, R.W., Pemberton, S.G., and Fagerstrom, J.A. 1984. Morphological, ethological and environmental significance of the ichnogenera Scoyenia and Ancorichnus. Journal of Paleontology, 58, pp. 511-528.

Gaillard, C., Hantzpergue, P., Vannier, J., Margerard, A-L., and Mazin, J-M. 2005. Isopod trackways from the Crayssac lagerstätte, Upper Jurassic, France. Palaeontology, 48, pp. 947-962. doi:10.1111/j.1475-4983.2005.00502.x

Gatesy. S.M., Middleton, K.M., Jenkins, F.A., and Shubin, N.H. 1999. Three-dimensional preservation of foot movements in Triassic theropod dinosaurs. Nature, 399, pp. 141-144. doi: $10.1038 / 20167$

Geinitz, H.B. 1849. Das Quadersandsteingebirge oder Kreidegebirge in Deutschland. Craz und Gerlach, Freiberg. $292 \mathrm{p}$.

Gemballa, S., and Bartsch, P. 2002. Architecture of the integument in lower teleostomes: functional morphology and evolutionary implications. Journal of Morphology, 253, pp. 290-309. doi:10.1002/jmor.10007

Getty, P.R. 2005. Excavated and in situ dinosaur footprints from the Murray Quarry (Early Jurassic East Berlin Formation), Holyoke, Massachusetts, USA. Ichnos, 12, pp. 163-178. doi:10.1080/10420940591008999

Gierlowski-Kordesch, E. 1985. Sedimentology and trace fossil paleoecology of the lower Jurassic East Berlin Formation, Hartford Basin, Connecticut and Massachusetts. Unpublished Ph.D. thesis, Case Western Reserve University, Cleveland, Ohio, $228 \mathrm{p}$.

Gierlowski-Kordesch, E. 1991. Ichnology of an ephemeral lacustrine/alluvial plain system: Jurassic East Berlin Formation, Hartford Basin, USA. Ichnos, 1, pp. 221-232. doi:10.1080/10420949109386354

Gillette,L.,Pemberton, S. G., and Sarjeant, W.2003. A Late Triassic invertebrate ichnofauna from Ghost Ranch, New Mexico. Ichnos, 10, pp. 141-151. doi:10.1080/10420940390255493

Good, S.C. 2004. Paleoenvironmental and paleoclimatic significance of freshwater bivalves in the Upper Jurassic Morrison Formation, western interior, USA. Sedimentary Geology, 167, pp. 163-176. doi:10.1016/j.sedgeo.2004.01.005

Hagadorn, J.W., and Miller, R.F. 2011. Hypothesized Cambrian medusae from Saint John, New Brunswick, reinterpreted as sedimentary structures. Atlantic Geology, 47, pp. doi: 10.4138/atlgeol.2011.002

Haldeman, S.S. 1840. Supplement to number one of "A monograph of the limniades, or freshwater univalve shells of North America", containing descriptions of apparently new animals in different classes, and the names and characters of the subgenera in Paludina and Anculosa. J. Dobson, Philadelphia, PA. 3 p.

Hall, J. 1847. Paleontology of New York. Volume 1. C. Van Benthuysen, Albany, New York. 338 p.

Hall, J. 1852. Paleontology of New York. Volume 2. C. Van Benthuysen, Albany, New York. 362 p.

Häntzschel W. 1975. Trace fossils and problematica. In Treatise on invertebrate paleontology, part W, miscellanea, supplement 1. Edited by C. Teichert. Geological Society of America and University of Kansas Press, Boulder and Lawrence, USA. 269 p.

Hasiotis, S.T. 2002. Continental trace fossils. SEPM Short Course Notes 51. SEPM, Tulsa, Oklahoma. $132 \mathrm{p}$.

Hasiotis, S.T., and Bown, T.M. 1992. Invertebrate trace fossils: the backbone of continental ichnology. In Trace fossils. Short courses in paleontology. Edited by C.G. Maples and R.R. West. The Paleontological Society, Lawrence, Kansas, 64-104.

Hitchcock, E.H. 1845. An attempt to name, classify, and describe the animals that made the fossil footmarks of New England. Proceedings of the 6th Annual Meeting of the Association of American Geologists and Naturalists, New Haven, Connecticut, 6, pp. 23-25.

Hitchcock, E.H. 1865. Supplement to the ichnology of New England. A report to the government of Massachusetts, in 1863. Wright and Potter, Boston, Massachusetts. 96 p.

Hubert, J.F., and Dutcher, J.A. 2010. Scoyenia escape burrows in fluvial pebbly sand: Upper Triassic Sugarloaf Arkose, Deerfield Rift Basin, Massachusetts, USA. Ichnos, 17, pp. 20-24. doi:10.1080/10420940903358529

Hubert, J.F., Feshbach-Meriney, P.E., and Smith, M.A. 1992. The Triassic-Jurassic Hartford Rift Basin, Connecticut and Massachusetts: evolution, sandstone diagenesis, and hydrocarbon history. The American Association of Petroleum Geologists Bulletin, 76, pp. 1710-1734.

Huene, F. von. 1941. Die Tetrapoden Fährten im toskanischen Verrucano und ihre Bedeutung. Neues Jahrbuch für Mineralogie Geologie und Paleontologie, 86, pp. 1-34.

Karaszewski, W. 1973. A star-like trace fossil in the Jurassic of the Holy Cross Mts. Bulletin De L'Académie Polonaise des Sciences, Serie des Sciences de la Terre, 21, pp. 157-160.

Keighley, D.G., and Pickerill, R.K. 2003. Ichnocoenoses from the Carboniferous of eastern Canada and their implications for recognition of ichnofacies in nonmarine strata. Atlantic Geology, 39, pp.1-22.

Kim, J.Y., Keighley, D.G., Pickerill, R.K., Hwang, W., and Kim, K.S. 2005. Trace fossils from marginal lacustrine deposits of the Cretaceous Jinju Formation, southern coast of Korea. Palaeogeography, Palaeoclimatology, Palaeoecology 218, pp. 105-124. doi:10.1016/j.palaeo.2004.12.008

Lawfield, A.M.W., and Pickerill, R.K. 2006. A novel contemporary fluvial ichnocoenose: unionid bivalves and the Scoyenia- 
Mermia ichnofacies transition. Palaios, 21, pp. 391-396. doi:10.2110/palo.2006.P06-08

Levinton,J.S. 1971. Control of tellinacean (Mollusca: Bivalvia) feeding behavior by predation. Limnology and Oceanography, 16, pp. 660-662. doi:10.4319/lo.1971.16.4.0660

Lull, R.S. 1904. Note on the probable footprints of Stegomus longipes. American Journal of Science, 17, pp. 381-382. doi:10.2475/ajs.s4-17.101.381

Lull, R.S. 1953. Triassic life of the Connecticut Valley, revised. Connecticut Geological and Natural History Survey Bulletin, $81.336 \mathrm{p}$.

MacNaughton, R.B., and Pickerill, R.K. 1995. Invertebrate ichnology of the Lepreau Formation (Triassic), southern New Brunswick, eastern Canada. Journal of Paleontology, 69, pp. 160-171.

McCune, A.R. 1996. Biogeographic and stratigraphic evidence for rapid speciation in semionotid fishes. Paleobiology, 22, pp. 34-48.

McCune, A.R. 2004. Diversity and speciation of semionotid fishes in Mesozoic rift lakes. In Adaptive speciation. Edited by U. Dieckmann, M. Doebeli, J.A.J. Metz, and D. Tautz. Cambridge University Press, Cambridge, pp. 362-379.

McDonald, N.G. 1992. Paleontology of the early Mesozoic (Newark Supergroup) rocks of the Connecticut Valley. Northeastern Geology, 14, pp. 185-200.

Melchor, R.N. 2004 . Trace fossil distribution in lacustrine deltas; examples from the Triassic rift lakes of the Ischigualasto-Villa Union Basin, Argentina. Geological Society Special Publications, 228, pp. 335-354. doi:10.1144/GSL. SP.2004.228.01.15

Metz, R. 1996. Newark basin ichnology: the late Triassic Perkasie Member of the Passaic Formation, Sanatoga, Pennsylvania. Northeastern Geology and Environmental Sciences, 18, pp. 118-129.

Milan, J. 2006. Variations in the morphology of emu (Dromaius novaehollandiae) tracks reflecting differences in walking pattern and substrate consistency: ichnotaxonomic implications. Palaeontology, 49, pp. 405-420. doi:10.1111/j.14754983.2006.00543.x

Nicholson, H.A. 1873. Contributions to the study of errant annelids of the older Palaeozoic rocks. Royal Society of London, Proceedings, 21, pp. 288-290.

Olsen, P.E. 1988. Paleontology and paleoecology of the Newark Supergroup (early Mesozoic, eastern North America). In Triassic-Jurassic rifting: continental breakup and the origin of the Atlantic Ocean and passive margins. Edited by W. Manspeizer. Elsevier Scientific Publications, Amsterdam, pp. $185-230$.

Olsen, P.E. 1997. Stratigraphic record of the early Mesozoic breakup of Pangea in the Laurasia-Gondwana rift system. Annual Review of Earth and Planetary Sciences, 25, pp. 337401. doi:10.1146/annurev.earth.25.1.337

Olsen, P.E, and Padian, K. 1986. Earliest records of Batrachopus from the southwestern United States, and a revision of some early Mesozoic crocodylomorph ichnogenera. In The beginning of the Age of Dinosaurs: faunal change across the
Triassic-Jurassic boundary. Edited by K. Padian. Cambridge University Press, Cambridge, pp. 259-273.

Olsen, P.E., and Rainforth, E.C. 2003. The Early Jurassic ornithischian dinosaurian ichnogenus Anomoepus. In The great rift valleys of Pangea in eastern North America, volume 2: sedimentology and paleontology. Edited by P.M. LeTourneau and P.E. Olsen. Columbia University Press, NY, pp. 314-368.

Olsen, P.E., Schlische, R.W., and Gore, P.J.W. (Editors). 1989. Tectonic, depositional, and paleoecological history of early Mesozoic rift basins, eastern North America. 28th International Geological Congress, Washington, D.C., Field Trip Guidebook T351. 174 p.

Olsen, P. E., McDonald, N. G., Huber, P., and Cornet, B., 1992, Stratigraphy and Paleoecology of the Deerfield rift basin (Triassic-Jurassic, Newark Supergroup), Massachusetts. In Guidebook for field trips in the Connecticut Valley region of Massachusetts and adjacent states (vol.2), New England Intercollegiate Geological Conference 84th Annual Meeting. Edited by P. Robinson and J.B. Brady, Contribution no. 66, Department of Geology and Geography, University of Massachusetts, Amherst, Massachusetts, p. 488-535.

Olsen, P.E., Smith, J.B., and McDonald, N.G. 1998. Type material of the type species of the classic theropod footprint genera Eubrontes, Anchisauripus, and Grallator (early Jurassic, Hartford and Deerfield Basins, Connecticut and Massachusetts, U.S.A.). Journal of Vertebrate Paleontology, 18, pp. 586-601. doi:10.1080/02724634.1998.10011086

Olsen, P.E., Whiteside, J.H., LeTourneau, P.M., and Huber, P. 2005. Jurassic cyclostratigraphy and paleontology of the Hartford Basin. In 97th New England Intercollegiate Geological Conference. Department of Geology and Geophysics, Yale University, New Haven, Connecticut, pp. A4-1-A4-51.

Osgood, R.G. 1970. Trace fossils of the Cincinnati area. Palaeontographica Americana, 6, pp. 281-444.

Pemberton, S.G., and Frey, R.W. 1982. Trace fossil nomenclature and the Planolites-Palaeophycus dilemma. Journal of Paleontology, 56, pp. 843-881.

Pflüger, F. 1999. Matground structures and redox facies. Palaios, 14, pp. 25-39. doi:10.2307/3515359

Pickerill, R.K. 1992. Carboniferous nonmarine invertebrate ichnocoenoses from southern New Brunswick, eastern Canada. Ichnos, 2, pp. 21-35. doi:10.1080/10420949209380072

Rainforth, E.C. 2003. Revision and re-evaluation of the Early Jurassic dinosaurian ichnogenus Otozoum. Palaeontology, 46, pp. 803-838. doi:10.1111/1475-4983.00320

Rainforth, E.C. 2005. Ichnotaxonomy of the fossil footprints of the Connecticut Valley (Early Jurassic, Newark Supergroup, Connecticut and Massachusetts). Unpublished Ph.D. thesis, Columbia University, New York, 1301 p.

Reineck, H. E., and Singh, I. B. 1980 Depositional sedimentary environments. Springer-Verlag, Berlin, $551 \mathrm{p}$.

Ricci Lucchi, F. 1995. Sedimentographica: photographic atlas of sedimentary structures. Columbia University Press, New York, $255 \mathrm{p}$. 
Richter, R. 1937. Marken und Spuren aus allen Zeiten. Seckenbergiana, 19, pp. 150-169.

Sarkar, S., Banerjee, S., Samanta, P., and Jeevankumar, S. 2006. Microbial mat-induced sedimentary structures in siliciclastic sediments: examples from the $1.6 \mathrm{Ga}$ Chorhat Sandstone, Vindhyan Supergroup, M.P., India. Journal of Earth System Science, 115, pp. 49-60. doi:10.1007/BF02703025

Schaeffer, B. 1952. The Triassic coelacanth fish Diplurus, with observations on the evolution of Coelocanthini. Bulletin of the American Museum of Natural History, 99, pp. 29-78.

Schlirf, M., and Uchman, A. 2005. Revision of the ichnogenus Sabellarifex Richter, 1921 and its relationship to Skolithos Haldeman, 1840 and Polykladichnus Fürsich, 1981. Journal of Systematic Palaeontology, 3, pp. 115-131. doi:10.1017/ $\underline{S 1477201905001550}$

Schlirf, M., Uchman, A. and Kümmel, M. 2001. Upper Triassic (Keuper) non-marine trace fossils from the Hassberge area (Franconia, south-eastern Germany). Paläontologische Zeitschrift, 75, pp. 71-96.

Schlotheim, E.F. 1820. Die Petrefaktenkunde auf ihrem jetzigen Standpunkte durch die Beschreibung seiner Sammlung versteinerter und fossiler Berreste des Thier- und Planzenreichs erlutert. Beckersche Buchhandlung, Gotha. 437 p.

Smith, R.M.H., Mason, T.R., and Ward, J.D. 1993. Flash-flood sediments and ichnofacies of the late Pleistocene Homeb Silt, Kuiseb River, Namibia. Sedimentary Geology, 85, pp. 579-599. doi:10.1016/0037-0738(93)90103-C
Uchman, A., Kazakauskas, V., and Gaigalas, A. 2009. Trace fossils from Late Pleistocene varved lacustrine sediments in eastern Lithuania. Palaeogeography, Palaeoclimatology, Palaeoecology, 272, pp. 199-211. doi:10.1016/j.palaeo.2008.08.003

Voigt, S., Small, B., and Sanders, F. 2005. A diverse terrestrial ichnofauna from the Maroon Formation (PennsylvanianPermian), Colorado: biostratigraphic and paleoecological significance. New Mexico Museum of Natural History and Science Bulletin, 30, pp. 342-351.

White, D. 1929. Flora of the Hermit Shale, Grand Canyon, Arizona. Carnegie Institute of Washington, Publication 405, $221 \mathrm{p}$.

Wise, D.U. 1992. Dip domain method applied to the Mesozoic Connecticut Valley rift basins. Tectonics, 11, pp. 1357-1368. doi:10.1029/92TC01103

Wolela, A.M., and Gierlowski-Kordesch, E.H. 2007. Diagenetic history of fluvial and lacustrine sandstones of the Hartford Basin (Triassic-Jurassic), Newark Supergroup, USA. Sedimentary Geology, 197, pp. 99-126. doi:10.1016/j.sedgeo.2006.09.006

Young, G.A., and Hagadorn, J.W. 2010. The fossil record of cnidarian medusa. Palaeoworld, 19, pp. 212-221. doi:10.1016/j. palwor.2010.09.014

Editorial responsibility Robert A. Fensome 